\title{
CLOSING LECTURE AT THE XVI INTERNATIONAL CONGRESS OF BIEN, SEOUL, SOUTH KOREA, JULY 7-9, 2016
}

\author{
Eduardo Matarazzo Suplicy \\ Departamento de Economia da EAESP/FGV, São Paulo, \\ Doutor em Economia pela Universidade de Michigan-EUA, \\ Senador da República (1990-2014), \\ Vereador de São Paulo \\ Email: eduardo@eduardosuplicy.com.br
}

Recebido em: 29.05.2016 - Aceito em: 12.12.2016

Lecture to The International Seminar on the Basic Income or the Universal Citizen's Income organized by the Mexican Senate and CEPAL, April 19-20, 2016

Contribution to the book "Integral Policy towards the First Infancy" about the São Paulo Carinhosa Program and Brazil Carinhoso Program (São Paulo and Brazil Caressing Programs), of the Municipality of São Paulo Program of Mayor Fernando Haddad, June 2016

My dear participants of the XVI International Congress of the Basic Income Earth Network, of the International Seminar on the Basic Income organized by the Mexican Senate and CEPAL, and to all that have interacted with me in the Municipality of São Paulo, especially Mrs. Ana Estela Haddad, Coordinator of the São Paulo Carinhosa Program.

It is an honor for me to be invited by Mr. Hyosang Ahn and the organizers of this XVI International Congress of BIEN in Seoul, South Korea, to deliver the closing lecture of this event, the first Congress of BIEN that is realized in Asia, as well to The Mexican Senate and CEPAL Seminar, and members of the São Paulo Carinhosa Program. Since the Basic Income European Network became the Basic Income Earth Network, in the Tenth International Congress held in Barcelona, in 2004, we had the XI in Capetown, South Africa, 2006; the XII in Dublin, Ireland, in 2008; the XIII in São Paulo, Brazil, in 2010; the XIV in Munchën, Germany, in 2012; and the XV in Montreal, in Canada.

When a good thing happens to a person, it is good for him to tell his friends what happened. Thus, I would like to inform you that last February 2, I was so happy when the Catholic University of Louvain granted to me, the title of Doctor Honoris Causa, together with the Italian Architect, Paola Viganò, and the American Founder of the Wikipedia, Jimmy Wales, when they comemorated the 500 hundred years of the publication of "Utopia", in which Thomas More explains so well the fundamentals of why we should guarantee the survival of all human beings. In the dialogue about 
the consequences of the death penalty, instituted in England at the beginning of the XVI Century, that had not contributed to diminish violent criminality, assaults, robbery and murders, the Portuguese traveler, Rafael Hitlodeu, then precisely observes to a Cardinal and another fellow: "Much more efficient than having no other alternative for a person first to become a thief to be then transformed into a corpse is to guarantee the survival of everyone". Based on that reflection, a friend of Thomas More, the Spanish Juan Louis Vives wrote to the Mayor of Bruges "De Subventione Pauperum De Site Necessitabus", A Treatise on Poverty, in which, for the first time, he proposes a guaranteed income to the inhabitants of that city.

Because a study about the origins of this proposal had gained a premium in a contest organized by the King Baudouin Foundation, in 1984, its author used the fund that he had gained to organize a conference at the Catholic University of Louvain, in 1986, in which about fifty of the most dedicated authors of studies about how to eradicate poverty, diminish inequality and promote justice gathered there when they decided to found a Forum to study all forms of income transfers and ways of attaining the objectives of building a just society. They came to the conclusion that it would be important to create a Forum that would struggle to institute an Unconditional Basic Income in all countries of Europe. When having dinner at that meeting, one of the fellows said BIEN. And the other said: that's a good word. And so they founded the Basic Income European Network, BIEN. This year BIEN completes 30 years. Since 1986, BIEN has organized International Congresses where Economists, Philosophers, Sociologists, Social Scientists and Activists from all nations meet every two years to debate the advances of the proposal.

I was born in São Paulo, in 21/06/1941, in a very beautiful and comfortable house, the eighth of eleven brothers and sisters that my parents Paulo Cochrane Suplicy and Filomena Matarazzo Suplicy had. My mother decided to have me at home instead of in the maternity. She told me that I gave much trouble because of having been born with a very big head. Although being born in a well off Family, thanks mainly to the values and examples transmitted by my parents, such as telling me and my brothers and sisters that we should always be united and that the values of fraternity and solidarity should prevail. But they also told us that these values should be practiced beyond the walls of our home. Since my boyhood and adolescence I have noticed that around the people with whom I used to live we had all the facilities to have a good life, educational opportunities, cars, places of vacation and so on. But in our city, despite its rapid progress, and in our country, we could see so many people who were still poor, sleeping in the streets or living 
in the favelas, slums, and having few opportunities. Being a good sportsman that practiced soccer, basketball, swimming, volleyball and so many sports, from my 15 to years of age I also practiced boxing in several academies in São Paulo. That was a sport mainly practiced by members of the working class. I became friend of many of them and tried to understand their difficulties.

I had my studies in good catholic schools, the elementary course at the Escola Nossa Senhora das Graças, and the high school at the Colégio São Luiz. When I was 15 years of age I read the biography of Galileo Galilei and saw the film about Nicolau Copérnico. I became enthusiastic about how important it was their will to find the truth. Then I decided to do my bachelor's in Business Administration at Fundação Getúlio Vargas. I stopped for one semester after the second year to spend some time visiting the countries in Eastern and Western Europe to know better what was socialism, capitalism, Marxism, the progress of the Common Market and of the socialist countries. After travelling through 14 countries and visiting the Berlim Wall I became convinced that it would be important to struggle for a better world through democratic and non-violent means. Once finished my BA in Business I worked for a year at the Escriptorio Suplicy, with my father. But in February 1966 , I told my parents that I would like to participate in a concourse to become a Professor of Economics at the Escola de Administração de Empresas de São Paulo, of the Getúlio Vargas Foundation. Being successful, then I was able to complete my Master's (1968) and later the Ph.D. in Economics (1973) at Michigan State University, with a 15 months period of studies at Stanford University. During this time, I became familiar with the concept of a guaranteed income introduced in the form of a negative income tax, as one of the forms to eradicate poverty.

After returning to Brazil, in addition to teach at the Getulio Vargas Foundation, I started to publish articles in the Brazilian press, for Última Hora, Visão and mainly Folha de S. Paulo. In 1976, some friends told me: Your articles are being quiet read, especially by the youth. We think that you should consider being a People's Representative. In 1978, I was elected State Deputy representing the MDB, the Brazilian Democratic Movement. In 1980, I was a co-founder of The PT, the Worker's Party. In 1982, I was elected Federal Deputy, in 1988, City councilman and President of the São Paulo City Council. In 1990, 1998 and 2006, I was elected a Senator representing the PT and the State of São Paulo. Already in April 1991, I presented to the Senate a first Project of law to institute a Guaranteed Minimum Income through a Negative Income Tax, which was approved by the Senate in December 1991. 
From the debate about it among economists, Professor José Márcio Camargo, of the Catholic University of Rio de Janeiro, observed that a Guaranteed Minimum Income should be provided first to poor families with young children, as long as they were going to school. This would be a way to cut one of the vicious circle of poverty. He wrote articles about that. In 1995, three experiences along these lines started in the Federal District, in Campinas and in Ribeirão Preto. The positive results made the idea spread over several municipalities. Several projects of law appear in the National Congress. In 1997, President Fernando Henrique Cardoso sanctioned a Law saying that the Union would finance $50 \%$ of the projects of that nature in the Brazilian municipalities. This became even more relevant in 2001 when he extended to $100 \%$ of the expenses to all municipalities of Brazil that would apply the Guaranteed Minimum Income Program related to educational opportunities, also called Bolsa Escola Programs. Then came the Bolsa Alimentação, the Gas Aid Programs, and already in 2003, the Food Card Program instituted by President Luiz Inácio Lula da Silva. In October 2003, President Lula decided to unify and rationalize those four programs into the Bolsa Família Program that provides a complement of income to all families with an income per capita below a certain level, today $\mathrm{R} \$ 154$ per capita per month, as long as some condionalities related to educational and health opportunities are satisfied.

Since 1992 I started to become familiar with the concept of an Unconditional Basic Income. In 1994, I participated in the V International Congress of BIEN, when I interacted with all of his members. Since then I participated in all of the International Congresses of BIEN, except that of 1998, in Amsterdam, since it almost coincided with the Brazilians election for the Senate. More and more, I became persuaded that it would be the best form to eradicate poverty, build a just society and provide real freedom and dignity to all. In December 2001, I presented a new Project of Law in the Brazilian Senate to institute a Citizen's Basic Income to all Brazilian residents, including foreigners living there for five years or more, unconditionally. When the rapporteur studied the proposal, Senator Francelino Pereira, 81 years old, from the PFL, a more conservative party, he told me: "Eduardo, it is a nice idea, but you should make it compatible with the Law of Fiscal Responsibility, according to which, for each expense you need to have the correspondent revenue. Would you accept a paragraph that says that the CBI will be instituted step by step, under the Executive criteria, taking into account first those most in need, such as the Bolsa Família does it?" I reminded of the lessons of James Edward Meade in "Agathotopia", where he says that the important thing is to move firmly and grad- 
ually to the objectives that you believe that are the correct ones, because if you want to reach all the objectives at once, so many political instabilities might happen, such as he had seen along the Twenty Century that he had lived (1905-1995). I decided to accept that paragraph. Thanks to it, the Brazilian Senate, December 2002, and the Chamber of Deputies, December 2003, approved the proposal by all parties. It went to President Lula to sanction or not. The Minister of Finance Antonio Palocci told him: since it is to be introduced gradually, it is feasible, you may sanction it. So he did in January 8, 2016, twelve years ago.

Brazil became the first nation in the world to approve a law, by the National Congress, and sanctioned by the President, to institute an Unconditional Basic Income, although gradually. Since then I have been speaking to so many audiences all over Brazil and in other countries that we should advance towards the CBI. The Bolsa Família Program, that had 3.5 million families beneficiaries in December 2003 , today benefits 13.969 .599 million families. If we consider an average of 3.5 members per family, that corresponds to almost 50 million inhabitants or $1 / 4$ of our population of 204 million inhabitants. In the nineties we were the third most unequal nation in the world. We have made progress, but still we are the 16th most unequal nation in the world. Therefore, we need to consider all efforts, including better quality of education for all children, adolescents and adults, all measures to improve the quality of public health services, stimulate cooperatives, the microcredit, the expansion of the agrarian reform, greater housing opportunities, and also to institute the Citizen's Basic Income.

\section{THE CURRENT RULES OF THE BOLSA FAMÍLIA PROGRAM WILL BE DE- SCRIBED BELOW.}

Since July 2014, each family in Brazil with a monthly per capita income of less than $\mathrm{R} \$ 154.00$ became entitled to enjoy the benefits afforded by the Bolsa Familia Program 1 . On March 16, U\$1.00 was equivalent to $R \$ 3.7610$ and 1 Euro was equivalent to $R \$ 4.1790$. If the family income is less than $R \$ 77.00$, the basic benefit for the family is $R \$ 77.00$ plus $R \$ 35.00, R \$ 70.00, R \$ 105.00, R \$ 140.00$ or $R \$ 175.00$, respectively, if the family has one, two, three, four, five, or more children aged up to 15 years and 11 months; plus $R \$ 42.00$ and $R \$ 42.00$, totaling $R \$ 84.00$, if the family

1 The Brazilian Government considered the extreme poverty line defined by the World Bank, adopted by the United Nations Development Objectives of the Millennium, of U\$1.25 per capita per day, according to the Purchasing Power Parity, that in the beginning of the Brazil Without Misery Plan, June 2011, would mean around R\$67.00 per month. In March, 16, 2016 with US\$ 1.00 equal to R\$ 3.7610 , US\$ 1.25 would equal $R \$ 4,7125$ that times 30 days would be $\mathrm{R} \$ 141.0375$ per month. 
has one or two adolescents in the 16-18 age bracket. There are conditionalities: i) if the mother is pregnant, she must visit a public health facility regularly for prenatal testing and monitoring of her health until the baby is born; ii) parents must take their children aged up to six years to a public health facility to be vaccinated according to an immunization schedule prepared by the Ministry of Health; iii) children aged from seven to 15 years and 11 months must attend at least $85 \%$ of school days and adolescents in the 16-18 age bracket must attend at least $75 \%$ of school days.

Since the beginning of her administration, in January 2011, President Dilma Rousseff announced that her main objective is to eradicate extreme poverty in Brazil through the Brasil Sem Miséria (Brazil Without Extreme Poverty Program), the Bolsa Familia Program, and several other measures designed to ensure social inclusion for all Brazilians. These measures included the expansion of land reform; credit for family farmers; expansion of better educational opportunities; increase in the number of day-care centers; incentives for cooperatives; expansion of microcredit facilities; the Minha Casa, Minha Vida (My Home, My Life) public housing program; the Bolsa Verde (Green Grant) Program, which provides an income of $\mathrm{R} \$ 300.00$ for each three months for families living in protected areas such as forests, provided that they contribute to their conservation; the Luz para Todos (Electricity for All) Program, which makes electricity available in remote areas; construction of cisterns in dry areas to collect rain water during rainy seasons; as well as improvements in the Unified Health System, particularly through the construction of new health care units in areas where poor people live.

Regarding the Bolsa Familia Program, President Dilma announced in June 2011 that the Busca Ativa or Active Search. If a family that is entitled to enjoy the Bolsa Familia Program but still is not receiving its benefits then all State and municipal governments, civil organizations such as labor unions or business associations, normal citizens should tell the parents of this family that they have the right to enroll in the program and start receiving the benefits as explained above. This effort was meant to inform families about where they could apply for the program and enjoy its benefits in the respective municipal administration. The Ministry of Social Development and Fight Against Hunger estimates that more than 1,000,000 families have applied for the program since June 2011. The estimated budget for the Bolsa Familia Program in 2014 amounted to R $\$ 25.9$ billion, and in 2015 around $\mathrm{R} \$ 28.2$ billion or about $0.48 \%$ of Brazil's Gross Domestic Product of U\$ 5.8 trillion.

In May 2012, President Dilma Rousseff launched the Brasil Carinhoso (Caressing Brazil) Program, through which all families enjoying the benefits of the Bolsa 
Familia Program with children up to six years old receives an income supplement designed to make sure that their monthly income amounts to at least $R \$ 77.00$. New measures were also announced for all Brazil, such as an increase in the number of day-care centers to 1,512; besides kindergarten schools, construction of 6,427 new units by 2014; and initiatives in the health area, such as vitamin A and Iron supplementation for children in poor households and free provision of medicines against asthma.

In November 2012, President Dilma Rousseff announced the expansion of the Caressing Brazil Program, under which families with children and adolescents aged from 7 to 15 years old also became entitled to a financial supplement to ensure that the income level of all of its members were at least $\mathrm{R} \$ 77.00$ a month, as had been approved, in June of the same year, for families with children up to 6 years old. This expansion benefits 8.1 million children up to 15 years old. In total, the income supplement will became available to 16.4 million Brazilians, enabling them to overcome their situation of extreme poverty. The supplement began to be paid on December 10, 2012. Along with other economic policy instruments, the Bolsa Familia Program contributed to reducing extreme poverty and inequality levels in Brazil. The Gini coefficient, which had hit the mark of 0.599 in 1995 and 0.601 in 1996, decreased gradually every year to 0.569 in $2001 ; 0.569$ in 2002; 0.560 in 2003; 0.555 in 2004; 0.548 in 2005; 0.544 in 2006; 0.531 in 2007; 0.526 in 2008; 0.521 in 2009; 0.506 in 2011; 0.505 in 2012 and 0.501 in 2013. Those indexes take into account the remuneration of all sources. In 2014 and 2015, the Brazilian economy started to enter into a period of difficulties. There are signs that the Gini coefficient of inequality increased somewhat, together with lower rates of growth and higher unemployment.

It is relevant to register that a recent study published by Professors of the University of Brasília, Marcelo Medeiros, Pedro HGF Souza and Fabio Avila Castro, "A Estabilidade da desigualdade de renda no Brasil, 2006 a 2012, Ciência Saúde Coletiva (September 9, 2014) that takes into account not only the data collected by the National Research through Housing Samples (Pesquisa Nacional por Amostra de Domicílios - PNAD) but also the data of the Income Declaration to the Federal Revenue for Income Tax Revenues, shows that there was a stability in the inequality of income in Brazil from 2006 to 2012. These results were commented by Thomas Piketty in his recent visit to Brazil last November 2015. He said that we should have much more transparency in our income and wealth data and encourage Brazil to have a more progressive system of income and wealth taxation.

Despite the progress made, Brazil is still one the most unequal countries in the world. According to the 2010 IBGE Census, while the poorest 10 percent in 
Brazil earn only $1.1 \%$ of the country's total income, the richest 10 percent earn more than 44.5\%. In the 2012 World Bank list of countries by income equality, Brazil had the 16th highest Gini coefficient and was ranked 16th among the most unequal countries in the world. In order to advance more efficiently in eradicating extreme poverty and ensuring greater equality and real freedom for all its citizens, Brazil must implement the Citizen's Basic Income.

In 1992, when Antonio Maria da Silveira and I were very pleased with the passage by the Senate of the bill providing for a minimum guaranteed income through a negative income tax after he had returned from a trip to the United States and Europe, I asked him about the status of the debate on this subject. He said that a lot of people were talking about the unconditional basic income and gave me a copy of a book edited by Philippe Van Parijs called Arguing for basic income: ethical foundations for a radical reform (1992). My first reaction was that we should ensure a minimum income only to those who do don't earn enough to meet their basic needs. However, after studying the advantages of the proposal in the more specialized literature and after I began to attend congresses on the topic - since the 5th International BIEN Congress held in London and almost all the following ones - more and more I became an enthusiastic supporter of an unconditional Citizen's Basic Income (Renda Básica de Cidadania- RBC), to the point of devoting much of my energy and time to the cause even as a Brazilian senator elected three times to eight-year terms in 1990, with 4.2 million votes or $30 \%$ of all valid votes; in 1998, with 6.72 million votes or $43 \%$; and in 2006 , with $8,986,803$ votes, or $47.82 \%$.

In my last attempt to be elected Senator for the fourth time in the State of São Paulo, in October 2014, I was not successful. There was a sort of a Tsunami over the PT, the Worker's Party, in my State, affecting PT's position in every level. Whereas President Dilma Rousseff won the election in Brazil because of the positive results in other States, in São Paulo, in the first round she got only $25 \%$ of the votes. I had $32.5 \%$ of the votes, $6,176,499$ votes, and came in second place.

As a Professor of Economics at the São Paulo Business Administration School of the Getúlio Vargas Foundation, I continued to teach on Friday afternoons until December 2012, and as Senator I have been delivering lectures on the benefits of the RBC not only to my students and senators from the podium of the Senate or in its committees, but also in hundreds of auditoriums throughout Brazil and in many countries, where students, workers, social movements, businessmen, intellectuals, journalists, members of parliaments, executives, and their advisers at all levels of government are willing to learn about why we should ensure an RBC to everyone, regardless of one's origin, race, age, sex, civil or socioeconomic status. 
Prior to the municipal elections of 2012 for mayors and representatives in the City Councils held in all the 5,570 Brazilian municipalities, I tried to convince the candidates, particularly those from the Workers Party and from our parties in coalition, that they should have the objective of implementing the Citizen's Basic Income.

From August to November 2011, the Workers' Party held 33 plenary meetings in several different areas of São Paulo, Brazil's largest city, with a population of 12 million people, to which all of its members and sympathizers were invited to discuss and listen to what the five pre-candidates for mayor had to say. I was one of them. In all those meetings, I used half of my 15-minute time to explain the advantages of the Citizen's Basic Income. My arguments were approximately the following ones:

The Citizen's Basic Income will be made available to all citizens unconditionally. But should it be ensured even to those who are successful in their work, who are well-off and don't need a basic income to make ends meet? Yes. But of course those of us who have more than enough for our subsistence will contribute so that we and everyone else may enjoy this benefit.

It is much easier for everyone to understand that everybody has the right to receive, for example, from January on, an initial monthly income of, say, $\mathrm{R} \$ 100.00$, which over the following years will be raised to $R \$ 200.00, R \$ 500.00, R \$ 1,000$ and more as the city and Brazil grow, just like everybody has the right to enjoy, at least partially, the benefits afforded by the development of the nation. This is much easier to understand than the Bolsa Família Program, whose requirements and rules took at least three minutes to be explained.

With the RBC, we will eliminate all the paperwork involved in finding out how much each person is earning in the formal or informal market. We will also remove the stigma or feeling of shame of having to say that a person earns only a certain amount to justify the need of an income supplement.

We will eliminate the dependence phenomenon that is typical when you have a system that says: if a person doesn't earn a certain amount, he or she will be given an income supplement of this or that amount. The person is then considering whether to accept or not an economic activity that will result in such an income. But if the person accepts the activity and receives that amount, the government cuts what he or she was receiving under that cash transfer program, so he or she can decide not to work and fall in the unemployment or poverty traps. But if all people receive the RBC, they will always progress in any economic activity that they are engaged in.

But isn't this going to lead people to become lazy? What are we going to do with those who are not employed and are not interested in finding a job if they receive an $\mathrm{RBC}$ ? What are we going to do with those who have a natural tendency to freeload instead of working? In my talks, I usually ask if there are people in the audience that have this tendency. Often, no one raises their hand. When one or two people raise their hand, I invite to have a conversation with me before the audience. How can they be seen as freeloaders if they are there at that time of the day or night to discuss ideas on 
how to improve the quality of life for all?

Let us think about our human nature. Each one of us likes to do many things, even without earning any market income, such as mothers when they are breastfeeding their babies. Or when we, as parents take care of our children, making sure they are well fed, don't get hurt, are well educated, doing these things with love. Or when our parents and grandparents are older and they need our help. In all neighborhood associations, municipalities or churches of all religions or in student unions, how many of us would like to engage in many different activities simply because we like to feel useful? When the great painters Vincent van Gogh and Amedeo Modigliani painted their works they used to go out on the streets to try and sell them and make a living, but they could not make enough money to make ends meet. Both got sick and died early and today their paintings sell for millions of dollars.

Our Constitution, like those of many other countries, says that we respect private property. This means that if a person owns a factory, a farm, a bank, a hotel, a restaurant, a bond, real estate, that person has the right to an income from his or her property in the form of profits, interest or rentals. Does our Highest Law say that in order to receive earnings from property a person must necessarily confirm that he or she is working and sending his or her children and teenagers to school? No. And usually those who are better off financially work even on a voluntary basis during part of the day, in addition to sending their children to the best schools.

Therefore, if we allow those who are better off to earn an income from property without imposing any of these requirements on them, why not allow everyone, both rich and poor, to receive an RBC as a right of all citizens to enjoy a part of the common wealth of our city, state, and nation? This is a common-sense proposal, especially if we consider certain aspects of our history. Allow me to cite, as an example, the fact that for more than three centuries millions of people were taken from their homeland in Africa to contribute to the accumulation of capital by so many families without any remuneration and only to live in slave quarters and with such poor nutrition that slaves had a life expectancy of barely 30 years. Or when we consider recent aspects of our life, like the fact that former President Lula said that God is Brazilian, decided to live in Brazil and helped Petrobras, the Brazilian oil company, to find huge oil reserves in the bottom of the Atlantic Ocean in the pre-salt layer, which in the near future will make it possible for Brazil to actually eradicate extreme poverty, provide good educational opportunities for all, promote scientific, cultural and technical progress, have a good public health care system, and also protect the environment.

The most important advantage afforded by the RBC, however, is one that can be appreciated from the point of view of the dignity and freedom of every individual. From the point of view of what professor Amartya Sen, Nobel Laureate in Economics, mentioned in Development as Freedom (1999), namely, that to be meaningful and full, development must lead to greater freedom for the entire population. For example, for workers in rural areas or in the Amazon rainforest, which sometimes have no other choice but to accept working conditions that remind us of the days of slavery, or for a young person who, for lack of any other alternative to buy food for his or her children and family decides to sell his or her body, or for young men, such as those so appropri- 
ately described, for example, in the rap or hip-hop songs of the band Racionais MC's of Mano Brown, who have no other alternative to support their family than becoming a member of a gang of drug dealers. All individuals who begin to receive the RBC, including the members of their families, will be able to say NO to alternatives that will affect their dignity and health and put their lives at risk. They will be able to wait and perhaps enroll in a professional course until they can find a better opportunity according to their vocation and desire.

As so appropriately explained by Philippe Van Parijs in Real Freedom for All: What (if anything) can justify capitalism?, the RBC will raise the degree of freedom for all individuals. More than that, it will help society to better apply the principles of justice formulated by John Rawls in his book A Theory of Justice (1971). The principle of equal freedom, according to which everyone should enjoy a set of basic freedoms that should be extended to all persons in society; the principle of difference, according to which any socioeconomic difference in a society can only be justified if it exists for the benefit of those who have less, so as to make equal opportunities available for all. This is the principle of equal opportunities. Van Parijs argues that much beyond guaranteeing a minimum income through a negative income tax, as advocated by John Rawls, the RBC will be a useful tool for applying the three principles for all the above-mentioned advantages, especially that of eliminating stigmas. It will be much more efficient to put them into practice.

In the last of our 33 plenary meetings of the Worker's Party, in 2011, Fernando Haddad told the audience of around 1300 people that he had great respect for my struggle for the Citizen's Basic Income and that if he won the election for mayor of São Paulo, he would take into consideration the objective that we should consider the gradual implementation of the Basic Income, together with the efforts of the State and Federal Governments. When he mentioned that statement I said that I would join his efforts to be elected. He won the election for Mayor of São Paulo in October 2012, and became the Mayor for the 1913-1916 period. As a step towards the Citizen's Basic Income, he agreed that he would try to fulfill the aim of reaching the $100 \%$ objective towards the Active Search that is, providing the Bolsa Família Program to all families with monthly per capita income up to $R \$ 154.00$. In fact his government has advanced towards this aim. In December 2012, the last month of his predecessor, Mayor Gilberto Kassab, the number of families with monthly per capita income up to $R \$ 140.00$ ( the limit at the time) in the city of São Paulo were 444,718 . Of these 228,078 were enrolled and receiving the Bolsa Família benefits, that is $51.28 \%$. In February 2016 , the number of families with monthly per capita income up to $R \$ 154.00$ was 575,306 whereas the number of families enrolled and receiving the Bolsa Família benefits were 451,443 , that is $78.47 \%$. In fact, these proportions are somewhat higher because the families with monthly per capita 
income between $R \$ 77.00$ and $R \$ 154.00$, without children, do not have the right to the Bolsa Família benefits. Anyway, the results are of significant progress. Next October 2, we will have municipal election for Mayor and Fernando Haddad is again a candidate representing the PT. If he wins I will push forward the objective of moving São Paulo, today with 12 million inhabitants, towards the Citizen's Basic Income together with the State of São Paulo and Brazil.

Since June 2013, I have written 34 letters to President Dilma Rousseff proposing that I may have an audience with her to talk about the following measure: that she creates a Working Group to study the steps towards the Citizen's Basic Income. I have suggested 70 names among the best specialists on the areas of eradicating poverty, income transfer programs and socioeconomic policies. All 81 Senators, from all parties, have also signed a letter asking her to follow this recommendation. All BIEN members that were present in the XV International Congress of BIEN in Montreal, June 2014, signed a letter to her saying that they would be ready to contribute for these studies. For three times since December 2014, President Dilma Rousseff told me personally that she will receive me. I hope that this will happen as soon as possible. Perhaps, the Honor Doctoral Degree that the Catholic University of Louvain granted to me will help this to happen. I am sure that then Thomas More in haven will be very happy.

Since I am writing this paper in March, 2016, I really hope that until June President Dilma Rousseff will call me for us to talk about the studies that must be made for Brazil to implement the Citizen's Unconditional Basic Income. On this occasion I will have the opportunity to tell her how the BI proposition is spreading with greater force in all continents on Earth.

The most successful experience is that of Alaska that since 1982 is paying an equal dividend to all its residents living there for a year or more that is the result of the accumulation of the investments of royalties coming out of the exploitation of natural resources, mainly oil in the Alaska Permanent Fund. After 33 years, Alaska, that was the most unequal of the 50 American states in 1980, today, together with Utah, Alas$\mathrm{ka}$ is one the two equal of all American States. It is political suicide for any political leader there to propose the end of this system. In November 30, 2012, the Plenary Section of the Parlatino, in Panamá, approved by unanimity the Marc Law of the Basic Income, presented by me and the deputies Rodrigo Cabezas Morales, from Venezuela, Maria Soledad Vela Cheroni, from Ecuador, and Ricardo Berois, from Uruguay. It serves as a basis for a project to be presented to all parliaments of Latin America and the Caribbean. Like the Brazilian Law, it proposes a gradual implemen- 
tation of the Citizen's Basic Income. In Namibia, after the positive experiences of village of Otjivero, that happened thanks to the efforts of Bishop Zephania Kameeta, the President of the Namibian Coalition for a Basic Income, President Hage Geingob has recently announced a plan to eradicate absolute poverty until 2025 in which the Basic Income will have a central role. In India, in the State of Madya Pradesh, there was a very positive experience of a Basic Income coordinated by the Self Employed Women's Association, financed by UNICEF, with the aid of Professor Guy Standing. In Iran, in 2010, there was another pioneer experience with a Basic Income for the 75 million inhabitants, with the implementation of the law to end energy source subsidies. In Finland and in 20 municipalities such as Utrecht, in Holland, Basic Income experiences are being announced for 2017.In Switzerland, there will be a referendum in June 4, 2016, to ask the people whether they want or not to institute a Basic Income for the 8.1 million inhabitants. In Ontario, Canada, they recently announced that they will begin an experience of a Basic income. In the munipality of Maricá, in the Coast of Rio de Janeiro, Brazil, since last December a modest Basic Income of 10 mumbucas ( a social money) or 10 reais per month started to be paid to all 150.000 inhabitants. In the municipalities of Santo Antonio do Pinhal and Apiaí, in the State of São Paulo, laws were recently approved to institute gradually a Basic Income to all inhabitants. In Macau, a semi-autonomous city of the People's Republic of China, a former Portuguese possession, all 675,696 thousand inhabitants are receiving a Basic Income in the form of a "Wealth Partaking Scheme" since 2011. In 2015, all 607,465 permanent residents received 9,000 Macanese Pataca (about US\$ 1127) and non-permanent residents received 5,400 Macanese Pataca. (about US\$ 676). This has been possible mainly because of the Casino revenues. And so on, the Basic Income is being spread all over the Earth.

\section{REFERÊNCIAS}

Amartya Sen (1999a). Desenvolvimento como liberdade. São Paulo: Companhia das Letras publishing house, 2000.

John Rawls (1971). Uma teoria da justiça. São Paulo: Martins Fontes publishing house, 1997.

Philippe Van Parijs. (1995) Real freedom for all: what (if anything) can justify capitalism? Oxford: Oxford University Press.

Philippe Van Parijs. (1992) Arguing for basic income: ethical foundations for a radical reform. London: Verso. 